\title{
Faktor-Faktor yang Mempengaruhi Pinjaman Luar Negeri serta Imbasnya terhadap APBN
}

\author{
Samsubar Saleh \\ Universitas Gadjah Mada \\ samsubar@yahoo.com
}

The research and study cover a theoretical discussion and empirical study on factors affecting the Indonesian Government's foreign debt and their impact on the State Revenues and Expenditures Budget (APBN) based on annual data from 1970 to 2008. The research employs the Error Correction Model (ECM) approach by applying the Ordinary Least Square (OLS) method. The research results indicate that within a long-term period, there was a balance between changes in the Indonesian Government's foreign debts and macro-economic variables, i.e. budget deficit, exchange rate, export, GNP level, and dummy variables for the 1997 economic crisis, despite the fact that the budget deficit variable did not significantly affect the Indonesian Government's foreign debts within the observed period. On the other hand, within a short-term period changes in the Indonesian Government's foreign debts were affected significantly by dummy variables for the 1997 economic crisis and the ECT variable. Within such a period, the budget deficit, exchange rate, export, and GNP level variables did not significantly affect by the Indonesian Government's foreign debts. Thus, it could be concluded that the Indonesian Government's foreign debts tended to respond to changes occurring in macro-economic variables, especially export, exchange rate, economic growth, and condition of foreign debts post-1997 economic crisis.

Keywords: foreign debt, budget, balance, macro-economic.

\section{Pendahuluan}

$\mathrm{D}$ alam beberapa dekade terakhir kebijakan pinjaman luar negeri Indonesia selalu menjadi bagian yang tidak terpisahkan dalam sistem keuangan suatu negara sebagai salah satu sumber pembiayaan pembangunan dan menutupi defisit anggaran guna menunjang kondisi fiskal yang berkesinambungan. Kondisi pinjaman luar negeri Indonesia hingga saat ini memang telah mencapai jumlah yang sangat besar dan cukup memprihatinkan. Di samping itu juga menjadi dilema tersendiri bagi pemerintah karena di satu sisi pinjaman merupakan salah satu sumber penerimaan pemerintah dalam anggaran dan di sisi lain pembayaran pinjaman yang telah jatuh tempo juga menjadi beban dalam anggaran pemerintah sebagai pos pengeluaran yang harus diperhitungkan.

Krisis pinjaman luar negeri menjadi masalah yang sangat krusial dan menjadi beban perekonomian yang sangat berat. Pembayaran utang luar negeri tersebut setiap tahun bisa mencapai US\$6 miliar sampai US\$7 miliar. Dalam rupiah sekarang setara dengan jumlah uang sekitar $R p 60$ triliun-Rp 70 triliun (Media-Indonesia, 16 Juli 2007). Dalam APBN-P 2007 ditetapkan target pembiayaan luar negeri neto sebesar minus Rp 12,54 triliun (net transfer negatif). Artinya, pemerintah membayar pinjaman 
UNISIA, Vol. XXXI No. 70 Desember 2008

luar negeri lebih besar dibandingkan dengan penyerapan pinjaman baru. Pembayaran cicilan pokok utang luar negeri mencapai Rp 54,75 triliun, sedangkan pinjaman yang ditarik mencapai Rp 42,21 triliun (Kompas, 28 November 2007).

Dengan demikian, kondisi ini akan menciptakan hubungan sebab akibat antara penerimaan pinjaman dengan kewajiban membayar atas pinjaman yang digunakan. Hal ini juga akan menjadi sebuah tugas yang besar bagi pemerintah untuk melakukan manajemen anggaran yang menyangkut komitmen untuk membayar kembali pinjaman pemerintahnya dalam jangka waktu yang telah disepakati. Tingkat kemampuan suatu negara untuk membayar kembali (solvency) akan menjadi sebuah catatan tersendiri yang berimplikasi pada image atau penilaian secara makro ekonomi negara tersebut (Ramadhan dan Simanjuntak, 2007).

Pinjaman luar negeri itu sendiri dilakukan karena penerimaan pemerintah yang berasal dari pajak maupun penerimaan lainnya tidak mencukupi untuk membiayai pengeluaran pemerintah, baik untuk pengeluaran publik maupun pengeluaran aparatur. Dengan demikian pinjaman menjadi salah satu faktor yang menentukan akan terjadinya kesinambungan fiskal (fiscal sustainability) dari suatu anggaran negara. Dengan digunakannya pinjaman sebagai alat untuk menutupi defisit anggaran pemerintah, hal ini akan berimplikasi pada neraca pembayaran yang kemudian juga berimplikasi pada kinerja anggaran pemerintah. Dalam pemerintahan Indonesia, hal ini akan terkait erat dengan sejauh mana kemampuan pemerintah dalam manajemen fiskal dalam Anggaran Penerimaan dan Belanja Negara (APBN) dengan sebaik mungkin.

Sejak masa orde lama, Indonesia telah menggunakan pinjaman luar negeri sebagai cara untuk menutupi keterpurukan ekonomi pada masa itu, di mana sebagian besar pinjaman luar negerinya didapat dari Negaranegara Eropa Timur. Pada masa orde baru secara ekonomi mewarisi berbagai permasalahan yang terjadi pada orde lama, di mana mengalami gagal membayar pinjaman luar negerinya sebesar US\$2,4 miliar, hiperinflasi mencapai sebesar 600 persen, dan produksi industri yang hanya mencapai 20 persen dari kapasitasnya. Pada pemerintahan orde baru, sejak awal pemerintahannya melaksanakan kebijakan untuk meminjam ke luar negeri dalam rangka membiayai pengeluaran dalam anggaran. Pada tahun 1966, pinjaman luar negeri pemerintah mencapai US 2,105 miliar serta perjanjian pembiayaan pembangunan yang berasal dari luar negeri dimulai melalui Paris Club I pada 11 Maret 1966 yang akhirnya terbentuklah kelompok Negara donor yaitu Inter Governmental Group on Indonesia (IGGI) dengan pinjaman pertama diberikan kepada pemerintah Indonesia sebesar US\$ 200 juta (Ramadhan dan Simanjuntak, 2007).

Kemudian pada tahun 1970-an, pinjaman luar negeri pemerintah tumbuh rata-rata 16 persen per tahun. Namun kali ini pinjaman luar negeri pemerintah lebih banyak didominasi pinjaman dari bank dunia berupa program pinjaman sangat lunak, Internasional Development Assistance (IDA) tanpa bunga (hanya dibebani biaya administrasi) denganjangkawaktu 40 tahun. Pada tahun 1980-an, terjadi resesi global yang diakibatkan oleh kenaikan suku bunga pada negara-negara maju yang ternyata banyak termasuksebagai Negara kreditor pinjaman luar negeri pemerintah Indonesia. Dengan demikian, pada tahun 1983 pinjaman luar negeri Indonesia meningkat dari tahun sebelumnya sebesar 7 persen menjadi 20 persen.

Memasuki periode 1990-an, pada sebelum krisis tahun 1997, pertumbuhan pinjaman luar negeri pemerintah menunjukkan perkembangan yang semakin membaik 
Faktor-faktor Yang Mempengaruhi Pinjaman Luar Negeri...; Samsubar Saleh

dengan pertumbuhan rata-rata 2,24 persen per tahun. Namun memasuki Triwulan III 1997, perekonomian Indonesia mengalami goncangan yang sangat besar. Hal ini merupakan akibat efek penularan (contagion effect) krisis nilai tukar yang menimpa mata uang Tahiland, Bath, yang diikuti oleh negaranegara lainnya di Asia. Melonjaknya nilai tukar berdampak pada terjadinya defisit pada neraca pembayaran. Dengan kondisi inilah yang akhirnya memaksa pemerintah Indonesia untuk melakukan pinjaman terhadap International Monetary Fund (IMF).

Indonesia sendiri pada akhirnya memutuskan keluar dari fund facility program dari IMF pada akhir tahun 2003. Pada saat itu, total pinjaman luar negeri terhadap IMF mencapai US\$ 9,2 miliar, dan Indonesia masuk dalam Post Program Monitoring IMF yang baru berakhir tahun 2007.

Sementara tercatat posisi pinjaman luar negeri pemerintah Indonesia berdasarkan sumber pinjamannya periode tahun 2004 sampai oktober 2008 adalah sebagaimana Tabel (1).
Penarikan pinjaman luar negeri baru akan berdampak pada meningkatnya stock pinjaman luar negeri. Peningkatan terhadap stok pinjaman luar negeri akan berdampak terhadap beban bunga dan cicilan pinjaman luar negeri (Waluyo, 2006).

Dengan adanya kewajiban atas pinjaman luar negeri pemerintah, hal ini telah memberikan tekanan APBN yang sangat besar sehingga mengurangi kemampuan pemerintah untuk melakukan fiscal stimulus bagi pertumbuhan ekonomi. Akibat beban untuk memenuhi kewajiban pinjaman yang begitu besar, maka membuat permasalahan telah bergeser dari fiscal stimulus menjadi fiscal sustainability. Artinya, yang perlu dipikirkan dan dilakukan adalah langkahlangkah strategis di berbagai bidang untuk menjamin agar Indonesia terhindar dari krisis fiskal yang dapat berdampak sangat destruktif terhadap pertumbuhan ekonomi kita di masa yang akan datang.

Fenomena pinjaman luar negeri pemerintah hendaknya mendapat perhatian

Tabel (1). Posisi Pinjaman Luar Negeri Pemerintah berdasarkan Sumber Pinjaman

(dalam Miliar USD)

\begin{tabular}{|c|c|c|c|c|c|c|c|c|}
\hline \multirow[b]{2}{*}{ No. } & \multirow[b]{2}{*}{ Uraian } & \multicolumn{7}{|c|}{ Tahun } \\
\hline & & 2004 & 2005 & 2006 & 2007 & Q1 2008 & Q2 2008 & $\begin{array}{c}\text { Oktober } \\
2008^{*} \text { ) }\end{array}$ \\
\hline a. & BILATERAL & 34.27 & 32.32 & 31.83 & 32.14 & 34.33 & 33.23 & 33.42 \\
\hline b. & MULTILATERAL & 19.46 & 18.78 & 18.84 & 19.05 & 18.77 & 18.80 & 18.35 \\
\hline c. & EXPORT CREDIT & 13.68 & 11.63 & 11.22 & 10.98 & 11.33 & 11.07 & 10.28 \\
\hline d. & COMMERCIAL CREDIT & 0.07 & 0.06 & 0.07 & 0.06 & 0.06 & 0.06 & 0.05 \\
\hline e. & LEASING & 0.22 & 0.22 & 0.06 & 0.02 & 0.01 & 0.01 & 0.00 \\
\hline f. & BONDS AND NOTES & 0.17 & 0.17 & - & - & - & - & - \\
\hline Tota & I Utang Pemerintah & 68.58 & 63.09 & 62.02 & 62.25 & 64.49 & 63.17 & 62.10 \\
\hline
\end{tabular}

Sumber: Direktorat Jendral Pengelolaan Utang

*)AngkaSementara

Catatan : Data di-update tgl. 31 Oktober 2008 
UNISIA, Vol. XXXI No. 70 Desember 2008

dan penanganan yang serius karena hal ini sangat terkait dengan pengelolaan keuangan negara baik di sisi penerimaan, ketika memperoleh pinjaman baru, maupun di sisi pengeluaran, saat harus membayar pinjaman yang jatuh telah tempo. Permasalahan yang juga perlu ditekankan dalam hal ini adalah pinjaman luar negeri yang senantiasa dijadikan solusi pembiayaan terhadap struktur APBN yang dari tahun ke tahun selalu menunjukkan posisi yang dilematis. Pertanyaan selanjutnya adalah apa sebaiknya yang harus dilakukan pemerintah terhadap kondisi pinjaman luar negeri saat ini serta dampak yang ditimbulkan terhadap APBN. Oleh karena itu, tulisan ini dimaksudkan untuk menganalisis faktor-faktor apa saja yang mempengaruhi pinjaman luar negeri pemerintah Indonesia serta imbasnya terhadap APBN.

\section{Kajian Pustaka}

\section{Hasil-hasil Penelitian Sebelumnya dan Landasan Teori}

Riset mengenai masalah pinjaman luar negeri baik di Indonesia maupun di beberapa negara lainnya telah menjadi perhatian banyak pihak dan cenderung menunjukkan hasil yang relatif berbeda secara kontekstual antara satu dengan yang lainnya.

Javed dan Sahinoz (2005) melakukan penelitian di Turki menyangkut External Debt: Some Experience from Turkish Economy dengan menggunakan regresi OLS sebagai alat anlisis, menunjukkan bahwa pinjaman luar negeri berpengaruh positif terhadap pertumbuhan dan ekspor, tetapi persamaan pertumbuhan tidak signifikan, sementara berdampak negatif terhadap investasi. Demikian pula dengan indikator-indikator pinjaman, antara lain rasio ekspor terhadap pinjaman luar negeri, \& pembayaran bunga terhadap penerimaan transaksi berjalan berpengaruh negatif meskipun pembayaran bunga terhadap ekspor, debt service terhadap ekspor tidak berdampak terhadap pertumbuhan.

Penelitian lainnya dilakukan oleh Karagol (1999) dengan metode 3SLS tentang External Debt and Economic Growth Relationship Using the Simultaneous Equations. Penelitian ini menunjukkan bahwa pembayaran pinjaman berhubungan dengan total pinjaman tahun sebelumnya dan ekspor, serta aliran modal masuk dipengaruhi oleh pertumbuhan ekonomi, juga ditunjukkan pengaruh langsung pembayaran pinjaman terhadap perekonomian adalah negatif. Dalam konteks Highly Indebted Poor Countries (HIPC) dan Non-HIPC, Cordella, Ricci, \& Arranz (2005) meneliti tentang Debt Overhang or Debt Irrelevance? Revisiting the Debt-Growth Link dengan menggunakan metode regresi OLS \& General Methods of Moments System Estimator (GMMS) di mana ditunjukkan bahwa di Highly Indebted Poor Countries (HIPC) pinjaman tidak berpengaruh terhadap pertumbuhan \& investasi berdasarkan sampel yang ada. Tetapi di Non-HIPC terdapat fakta bahwa keduanya saling berhubungan, dimana pinjaman naik pada tingkat yang cukup tinggi maka memiliki dampak marginal negatif terhadap pertumbuhan per kapita.

Martin (2008) dengan menggunakan analisis kuantitatif, Numerical Solution and Comparatif Statics melakukan kajian dan penelitian menyangkut $A$ positif Theory of Goverenment Debt yang menunjukkan bahwa kurangnya komitmen merupakan suatu fundamental friction yang menjelaskan tingkat nominal pinjaman, 
Faktor-faktor Yang Mempengaruhi Pinjaman Luar Negeri...; Samsubar Saleh

membantu kita memahami bagaimana kebijakan pemerintah saat ini tentang pengadaan dan penetapan yang rasional serta kurang jelasnya hubungan antara fundamental ekonomi dan tingkat pinjaman. Juga ditunjukkan bahwa pinjaman nominal cenderung ditentukan oleh mata uang domestik dan tidak ditunjukkan oleh inflasi.

Sementara itu, untuk kasus Indonesia telah pula dilakukan beberapa studi empiris yang terkait dengan pinjaman luar negeri, antara lain seperti yang dilakukan oleh Cholifihani (2008) mengenai A Cointegration Analysis of Public Debt Service and GDP in Indonesia. Analisis dilakukan melalui pengujian stasioneritas, kointegrasi dan ECM guna melihat keseimbangan jangka panjang antara variabel pengamatan. Penelitian tersebut menunjukkan bahwa GDP, debt service, capital stock, labor force dan human capital memiliki hubungan keseimbangan jangka panjang. Rasio antara ekspor, debt service menunjukkan hubungan yang negatif signifikan dengan GDP dalam periode jangka panjang.

Waluyo (2006) melakukan penelitian mengenai Dampak Pembiayaan Defisit Anggaran dengan Utang Luar Negeri Pemerintah terhadap Inflasi dan Pertumbuhan Ekonomi menggunakan metode TSLS, di mana ditunjukkan bahwa pembiayaan defisit anggaran dengan menggunakan utang luar negeri akan berdampak meningkatkan pertumbuhan ekonomi dan bersifat inflationary.

\section{Alasan-Alasan dan Dampak Penerimaan Pinjaman Luar Negeri}

Dari perspektif negara donor setidaknya ada dua hal penting yang memotivasi dan melandasi mengalirnya bantuan luar negeri ke negara-negara debitur. Kedua hal ini adalah motivasi politik (political motivation) dan motivasi ekonomi (economic motivation) yang keduanya mempunyai kaitan yang sangat erat antara yang satu dan yang lainnya (Zainulbasri 2000). Selain kedua alasan tersebut, dalam (Djamin 1993), juga dikemukakan adanya alasan moral sehingga diberikannnya pinjaman luar negeri. Dalam Hudianto (2005), disebutkan bahwa dilihat dari sisi teoritis, pinjaman pemerintah terjadi karena adanya tarikan dan dorongan. Teori yang mendasarkan kepada tarikan disebut dengan teori tarikan pinjaman (loan pull theory) dan teori yang mendasarkan diri pada dorongan disebut dengan teori dorongan pinjaman (loan push theory).

\section{1) Permintaan untuk berutang}

Dengan menggunakan teori tarikan pinjaman luar negeri, permintaan akan pinjaman luar negeri terjadi karena memang ada permintaan yang dilakukan oleh pemerintah negara peminjam. Ada dua kategori kemungkinan mengapa ada tarikan untuk berutang, antara lain sebagai berikut:

a. Adanya permintaan akan pinjaman luar negeri yang dilandasi oleh alasan ekonomi yang matang dan jelas terkait dengan proses peningkatan kapasitas produksi nasional.

b. Adanya permintaan pinjaman dari negara-negara sedang berkembang tanpa dilandasi oleh perhitungan ekonomi (efisiensi) melainkan oleh faktor acak (random). Faktor random erat kaitannya dengan perilaku para elit kekuasaan di negara sedang berkembang, yaitu perilaku korup dan tidak bertanggungjawab dalam memanfaatkan pinjaman luar negeri.

Dalam kategori kedua (tidak melalui pertimbangan ekonomis) sebenarnya juga 
UNISIA, Vol. XXXI No. 70 Desember 2008

termasuk di dalamnya permintaan pinjaman luar negeri yang dimaksudkan untuk mempertahankan nilai tukar yang tinggi sehingga impor barang konsumsi meningkat, serta dimaksudkan untuk mempertahankan cadangan devisa. Dua hal ini bisa dimaksudkan untuk kategori random yang tidak secara langsung berkait dengan peningkatan kapasitas produksi.

\section{2) Dorongan untuk berutang dari Negara Donor}

Mandel (dalam Hudianto, 2005) mengemukakan bahwa mengalirnya pinjaman luar negeri dari negara-negara maju ke negara sedang berkembang bukan hanya karena permintaan negara pengutang, namun juga merupakan desakan dari negaranegara yang mempunyai petro dolar. Dari teori tarikan dan dorongan, akhirnya pinjaman mengalir deras ke nagar-negara sedang berkembang. Kalau dorongan dan tarikan itu rasional dan bisa meningkatkan produksi nasional, tentu merupakan hal yang ideal. Ada kebutuhan, ada pasokan. Namun yang sering terjadi adanya desakan dari negara-negara maju untuk "melempar" kelebihan dana bertemu dengan tarikan permintaan yang tidak dilandasi oleh pertimbangan ekonomis, melainkan hanya untuk kepentingan para elit kekuasaan menangguk keuntungan pribadi atau golongan sebanyak mungkin. Karena jalinan kepentingan itu, banyak proyek di negara sedang berkembang tidak bisa dipertanggungjawabkan secara ekonomi. Terjadi kolaborasi antara kreditor yang akan menyalurkan dananya yang menganggur dan pejabat pemerintahan yang mempunyai interest pribadi sehingga objektivitas kelayakan proyek dipertanyakan karena tidak mempunyai justifikasi ekonomi. Kolaborasi antara loan pusher dengan pejabat pemerintah pada akhirnya menyebabkan pembengkakan nilai proyek (mark up) yang dibiayai dengan pinjaman luar negeri. Misalnya, kasus Balongan, Paiton dan berbagai kasus lainnya (Hudianto, 2005). Perilaku elit kekuasaan dalam berutang, pada akhirnya juga tampak pada bagaimana pengelolaan pinjaman luar negeri penuh dengan kebandelan atas batas bahaya yang secara umum dipakai sebagai acuan. Beberapa ambang bahaya yang selalu misalnya yang berkaitan dengan debt service ratio (DSR) dan ambang psikologis meksiko.

Debt Service Ratio (DSR) adalah ukuran umum yang sering dipakai untuk mempertimbangkan kemampuan suatu negara dalam menanggung beban pinjaman. Ukuran ini menunjukkan beban pinjaman yang harus dibayar dibanding dengan ekspor yang bisa dilakukan oleh suatu negara. Apabila peningkatan pinjaman luar negeri tidak diimbangi dengan meningkatnya kemampuan ekspor maka DSR akan meningkat. Sebaliknya, apabila peningkatan pinjaman luar negeri diimbangi dengan kemampuan meningkatkan besarnya ekspor (konsekuensi dari tanggung jawab berutang) maka DSR akan menurun.

Disamping itu, masalah mengenai dampak ekonomis yang ditimbulkan dari pinjaman luar negeri seperti halnya dengan swasta asing disatu pihak, yaitu para ekonom tradisional mengemukakan bahwa bantuan luar negeri telah membuktikan manfaatnya dengan mendorong pertumbuhan dan transformasi struktural di banyak negara berkembang (Todaro, 1994), (Basu, 1997) dalam (Lumadya, 2001). Namun pihak lain berpendapat bahwa dalam kenyataannya bantuan luar negeri tersebut sama sekali tidak mendorong pertumbuhan hingga menjadi lebih cepat, tetapi justru memperlambat pertumbuhan sehubungan dengan adanya substitusi terhadap investasi 
Faktor-faktor Yang Mempengaruhi Pinjaman Luar Negeri...; Samsubar Saleh

dan tabungan dalam negeri dan membesarnya defisit neraca pembayaran negara-negara berkembang, yang semuanya itu merupakan akibat dari meningkatnya kewajiban dunia ketiga untuk membayar pinjaman, serta sering dikaitkannya bantuan tersebut dengan keharusan menampung produk ekspor negara-negara donor (Todaro, 1994) dalam (Lumadya, 2001).

Solusi terhadap persoalan pinjaman ini memerlukan kerja keras secara kolektif dari berbagai pihak, yaitu debitor, kreditor internasional (baik negara, institusi donor, maupun bank-bank komersial), negaranegara industri sebagai pasar produk negara berkembang, serta tata ekonomi dunia pada umumnya (yang berpengaruh pada fluktuasi suku bunga) (Prasetiantono, 1996).

\section{APBN dan Kemampuan Membayar Pinjaman}

Suatu defisit atau surplus anggaran merefleksikan suatu ketidakseimbangan antara pengeluaran dan penerimaan pemerintah. Anggaran defisit adalah besarnya pengeluaran melebihi penerimaan yang diperoleh dari pajak, pembayaranpembayaran lain, dan ongkos pungutan retribusi. Sementara jika surplus berlangsung, maka kelebihan dana tersebut dapat digunakan untuk membayar dan mengurangi pinjaman pemerintah. Surplus anggaran akan meningkatkan tabungan nasional dan membuat dana yang tersedia di pasar kredit semakin besar. Peningkatan tabungan nasional dapat menurunkan tingkat bunga riil, yang berkontribusi pada peningkatan investasi dengan demikian meningkatkan pertumbuhan ekonomi (Hyman, 2005).

Kemampuan membayar pinjaman oleh pemerintah pada hakikatnya merupakan refleksi kemampuan APBN dalam menampung beban pembayaran bunga dan cicilan pinjaman pokok, yang sekaligus masih juga memberikan ruang gerak bagi pembiayaan untuk mendorong perekonomian. Dalam hal ini, satuan pengukur yang dipergunakan adalah "Primary Balance", yaitu surplus atau defisit APBN sebelum diperhitungkan pembayaran bunga pinjaman pemerintah. Ini berarti bahwa semua penerimaan pemerintah dikurangi dengan semua pengeluaran pemerintah di luar pembayaran bunga pinjaman (Harinowo, 2002).

Dalam sistem neraca pembayaran, peningkatan pinjaman luar negeri berarti meningkatkan pembayaran cicilan. Selanjutnya, hal ini akan menyebabkan kecenderungan net transfer negatif yang tidak bisa dibiayai dengan rekening transaksi berjalan mengingat transaksi berjalan yang kecil (bahkan negatif). Konsekuensinya adalah pemerintah mencari devisa lewat pinjaman luar negeri. Pinjaman luar negeri pemerintah akan meningkatkan cicilan pinjaman dan bunga dalam RAPBN yang merupakan komponen anggaran rutin berarti menurunkan anggaran pembangunan dalam RAPBN. Penurunan kemampuan membangun tidak lain berarti penurunan aktivitas pembangunan maupun pertumbuhan ekonomi bagi rakyat.

\section{Overlapping Generations Model}

\section{Pandangan Lerner}

Analisis dari sebuah overlapping generation model menunjukkan bagaimana beban dari sebuah pinjaman dapat ditransfer lintas generasi (Rossen, 2002). Dalam model Lerner, suatu generasi terdiri dari setiap orang yang hidup pada suatu waktu, serta diasumsikan bahwa populasi terdiri dari suatu jumlah yang sama dari anak 
UNISIA, Vol. XXXI No. 70 Desember 2008

muda, usia pertengahan, dan orang tua. Lerner beranggapan bahwa ketika pemerintah meminjam dari warga negaranya sendiri, maka kewajiban yang ada adalah sebuah pinjaman internal.

Menurut Lerner (1948), adanya hutang internal tidak menciptakan beban bagi generasi di masa depan. Para anggota generasi masa depan meminjamnya ke orang lain. Ketika hutang dibayar, ada sebuah transfer pendapatan dari satu kelompok warga negara (mereka yang tidak memiliki bond) ke orang lainnya (pemilik bond). Bagaimanapun juga, generasi masa depan secara keseluruhan tidak lebih buruk dalam hal di mana tingkat konsumsinya adalah sama seperti yang telah ada. Seperti yang dikatakan oleh penulis abad ke-18, Melon, 'tangan kanan meminjamkan ke tangan kiri' (Musgrave, 1985, hal. 49 dalam Rossen, 2002).

Hal ini cukup berbeda ketika sebuah negara meminjam dari luar negeri untuk mendanai pengeluaran saat ini. Ini disebut sebagai pinjaman eksternal. Dengan beranggapan bahwa uang yang dipinjam dari luar negeri digunakan untuk mendanai konsumsi saat ini, maka generasi masa depan tentu menanggung sebuah beban, karena tingkat konsumsinya dikurangi oleh satu jumlah yang sama dengan pinjaman ditambah dengan bunga yang ditambahkan yang harus dikirimkan ke penyedia dana dari luar negri. Jika, di sisi lain, pinjaman digunakan untuk mendanai akumulasi modal, hasilnya tergantung pada pro-duktivitas proyek. Jika pendapatan marginal dari investasi adalah lebih besar biaya marginal dana yang diperoleh dari luar, kombinasi pinjaman dan pengeluaran modal benar-benar membuat generasi masa depan menjadi lebih baik. Namun, ketika penda-patan proyek lebih kecil daripada biaya marginal, generasi masa depan adalah lebih buruk (Rossen, 2002).

\section{Model Neoklasik}

Rossen (2002) mengemukakan, bahwa model-model antar generasi yang dibahas sejauh ini tidak mengindikasikan adanya fakta bahwa keputusan-keputusan ekonomi dapat dipengaruhi oleh kebijakan pinjaman pemerintah, dan perubahan-perubahan dalam keputusan-keputusan ini memiliki akibat-akibat bagi mereka yang menanggung beban pinjaman. Namun, ada anggapan bahwa pajak-pajak yang dibebankan untuk membayar hutang tidak mempengaruhi perilaku kerja ataupun tabungan.

Model neoklasik tentang pinjaman menekankan bahwa ketika pemerintah memulai sebuah proyek, baik didanai oleh pajak-pajak atau pinjaman, sumber dayasumber daya dipindahkan dari sektor swasta. Seseorang biasanya menganggap bahwa ketika pendanaan pajak digunakan, sebagian besar sumber-sumber yang berpindah masuk pada pengeluaran konsumsi. Di sisi lain, ketika pemerintah meminjam, maka dia bersaing untuk danadana tersebut dengan individu-individu dan perusahaan-perusahaan yang menginginkan uang bagi proyek-proyek investasi pribadi mereka. Oleh karena itu, pada umumnya ada anggapan bahwa pinjaman memiliki efek paling besar pada investasi pribadi. Dalam kaitan di mana asumsi-asumsi ini adalah benar, pendanaan pinjaman meninggalkan generasi masa depan dengan sebuah stok modal yang lebih kecil, ceteris paribus (Rossen, 2002). Dengan demikian para anggota dari generasi ini kurang produktif dan cenderung memiliki pendapatanpendapatan riil yang lebih kecil daripada yang telah ada sekarang ini. maka, pinjaman memberikan sebuah beban bagi generasigenerasi masa depan melalui dampaknya pada pembentukan modal. Adanya asumsi bahwa pinjaman pemerintah mengurangi investasi pribadi memainkan sebuah peran 
Faktor-faktor Yang Mempengaruhi Pinjaman Luar Negeri...; Samsubar Saleh

penting dalam analisis neoklasik. Ketika pemerintah meningkatkan permintaannya untuk kredit, tingkat suku bunga, yang merupakan harga dari kredit, meningkat. Tapi jika tingkat suku bunga meningkat, investasi pribadi menjadi lebih mahal dan efek selanjutnya akan menyebabkan turunnya tingkat investasi tersebut.

\section{Model Ricardian}

Barro (1974) mengemukakan, bahwa ketika pemerintah meminjam, para anggota dari generasi 'tua' menyadari, bahwa keturunannya akan semakin buruk. Anggapan lebih lanjut bahwa generasi tua akan peduli terhadap kesejahteraan dari keturunanketurunannya dan oleh karena itu tidak ingin tingkatkonsumsi keturunannya akan berkurang di masa datang. Hipotesis provokatif Barro tentang ketidakrelevanan kebijakan fiskal pemerintah telah menjadi subyek dari banyak perdebatan. Beberapa menolak pemikiran yang didasarkan pada asumsi-asumsi yang luar biasa ini. Informasi tentang implikasi-implikasi dari defisit anggaran saat ini terhadap akan adanya beban-beban pajak di masa depan tidaklah mudah diperoleh.Oleh karena dalam kenyataannya, bahkan tidaklah mudah dan jelas berapa besar pinjaman yang sebenarnya. Kritikan lain yang cukup mendasar adalah, bahwa orang tidak berpandangan jauh dan akan melakukan antisipasi seperti yang diperkirakan dalam model ini.

Di sisi lain, dapat dikatakan bahwa ujian terakhir dari teori ini bukanlah logika dari asumsi-asumsinya, tetapi apakah ini mengarahkan pada prediksi-prediksi yang dipastikan oleh data atau tidak. Menurut pandangan kaum yang cenderung skeptis bahwa pada awal tahun 1980-an, ada banyak peningkatan dalam defisit anggaran negara. Jika model Ricardian adalah benar, maka dapat diharapkan tabungan pribadi atau swasta meningkat secara sepadan.
Pada waktu yang bersamaan pula, defisit anggaran federal meningkat, bagaimanapun juga, tabungan/penghematan swasta/pribadi (relatif terhadap produk rata-rata nasional) akan turun pula (Rossen, 2002).

\section{Krisis Pinjaman dan Pembayaran Cicilan utang serta Bunga}

Berdasarkan teori three gap model, hubungan antara besarnya pembayaran cicilan serta bunga pinjaman adalah positif. Semakin tinggi jumlah pinjaman luar negeri maka jumlah cicilan dan bunga yang harus dibayar juga akan meningkat (Supriyanto dan Sampurna, 1999:40 dalam Gunawan, 2005).

Krisis pembayaran pinjaman luar negeri suatu negara terjadi jika memenuhi tiga persyaratan berikut ini (Eaton dan Taylor, 1986 dalam Zainulbasri, 2000):

1. Tidak sanggup membayar (insolvent) atau tidak mampu membayar pinjaman dalam jangka panjang.

2. Tidak likuid (illiquid), yakni mereka tidak mempunyai cukup uang untuk membayar kewajiban saat jatuh tempo.

3. Tidak punya keinginan untuk membayar.

Pada kondisi pertama dan kedua sangat berhubungan dengan kemampuan suatu negara dalam memenuhi kewajiban-nya, dalam arti suatu negara mempunyai keinginan untuk membayar tetapi tidak mampu memenuhi kewajiban tersebut karena menghadapi masalah kekurangan (shortage) devisa luar negeri, sedangkan masalah terakhir lebih disebabkan oleh tidak adanya keinginan untuk membayar (unwillingness to pay) yang bisa saja dikarenakan adanya keuntungan-keuntungan ekonomis yang akan diraih atau karena alasan politis lainnya.

Krisis pinjaman dapat terjadi dalam berbagai bentuk. Pertama, negara atau 
UNISIA, Vol. XXXI No. 70 Desember 2008

kreditur menerima penundaan pembayaran cicilan namun tetap menerima pembayaran bunga pada jadwal yang telah disepakati. Kedua, kreditur menunda baik pembayaran kembali cicilan maupun bunganya sekaligus. Disamping kedua bentuk ini, masih banyak lagi variasi lain dari krisis pinjaman ini dan perlakuan dari kreditur terhadap penundaan ini juga bervariasi, misalnya pada kasus tertentu kreditur bersedia memperpanjang masa jatuh tempo (maturity) tetapi dengan menaikkan tingkat bunga pinjaman. Sementara dalam kasus yang lain justru tingkat suku bunga yang diturunkan sebagai upaya untuk mengurangi beban pinjaman negara yang bersangkutan.

\section{Metode Penelitian}

\section{Jenis dan Sumber Data}

Data yang digunakan dalam penelitian ini adalah data sekunder yang berbentuk data runtun waktu (time series) periode tahun 1970-2008. Data-data tersebut dikumpulkan dari beberapa sumber, antara lain: BAPPENAS, DEPKEU, BI, BPS, dan berbagai sumber terkait lainnya.

\section{Spesifikasi Model}

Model dasar yang digunakan merupakan modifikasi dari model persamaan yang digunakan oleh Karagol (1999). Penelitian tersebut menggunakan tiga persamaan, yaitu pertumbuhan ekonomi, pinjaman luar negeri, dan persamaan aliran modal masuk, sedangkan penelitian ini hanya menggunakan satu persamaan, yaitu persamaan pinjaman luar negeri:

dimana:

$$
\begin{aligned}
& G F D=\text { pinjaman luar negeri pemerintah } \\
& B D=\text { defisit anggaran }
\end{aligned}
$$

$E R=$ nilai tukar

I1997 = variabel dummy krisis ekonomi 1997

$E X R$ = tingkat ekspor

$Y R=$ tingkat GNP

et $=$ error term

$t \quad=$ indikator waktu

\section{Metode Analisis}

Estimasi yang akan dilakukan dalam penelitian ini menggunakan model ekonometri dinamis, khususnya Error Correction Model (ECM) dengan metode Ordinary Least Square (OLS). Model ECM digunakan untuk mengatasi adanya kemungkinan kesalahan atau perbedaan terutama diantara model teoritis dengan model statistik serta untuk melihat hubungan keseimbangan jangka panjang antar variabel pengamatan.

Kemudian untuk melihat dampak pinjaman luar negeri pemerintah Indonesia terhadap APBN dan perekonomian secara keseluruhan, maka digunakan pengukuran kuantitatif berdasarkan indikator pinjaman menurut Bank Dunia:

1. Rasio total pinjaman terhadap ekspor; (130\%-220\%)

2. Rasio pinjaman terhadap Produk Nasional Bruto (PNB); (50\%-80\%)

3. Debt Service Ratio; (<20\%).

Selengkapnya, analisis dilakukan melalui beberapa langkah atau tahapan pengujian yang berupa:

\section{Stasionaritas dan Kointegrasi}

Masalah stasionaritas data merupakan salah satu asumsi utama yang sering dilupakan orang di dalam pengukuran ekonometri yang menggunakan regresi. Pemenuhan asumsi ini akan mampu memberikan jaminan bahwa antara variabel dependen dan variabel independen memiliki 
Faktor-faktor Yang Mempengaruhi Pinjaman Luar Negeri...; Samsubar Saleh

hubungan jangka panjang, sehingga berguna bagi pengujian suatu hipotesa teoritis. Tanpa adanya asumsi ini, suatu hubungan antar variabel yang dihasilkan oleh persamaan regresi tidak bisa dijamin kebenarannya dalam jangka panjang. Dengan kata lain, hubungan yang ditemukan dari sebuah persamaan regresi yang diestimasi tersebut hanya benar oleh kasus itu sendiri, dan tidak ada jaminan bahwa persamaan itu bisa diberlakukan secara umum. Apabila hal itu terjadi, maka tujuan penelitian dan pengujian hipotesa menjadi tidak tercapai.

Asumsi stasionaritas memiliki konsekuensi penting bagi penerjemahan data dan model ekonomi, karena data yang stasioner akan memiliki variasi yang sangat kecil dan cenderung mendekati nilai rataratanya (Eangle dan Granger, 1987). Sebaliknya, data yang tidak stasioner cenderung dipengaruhi oleh waktu dan cenderung menyimpang menjauhi nilai rataratanya. Ketidakstasioneran suatu data bisa disebabkan oleh adanya hal-hal yang berkaitan dengan trend waktu polinomial, akar-akar unit dan derajat integrasi dari data (Insukindro, 1992).

Untuk mengatasi kemungkinan adanya masalah stasionaritas data yang pada dasarnya merupakan pra-kondisi atas sahihnya penggunaan estimasi OLS ini, maka dalam studi ini akan dilakukan pendekatan kointegrasi (cointegration approach) yang meliputi (lihat Granger, 1986:213; Insukindro, 1992:1-13):

1. Uji akar-akar unit yang digunakan untuk mengetahui stasionaritas suatu data.

2. Uji derajat integrasi yang digunakan untuk mengetahui pada derajat berapa data tersebut akan stasioner.

3. Uji kointegrasi yang baru dapat dilakukan apabila data yang diestimasi memiliki derajat integrasi yang sama, dan digunakan untuk mengetahui stasionaritas residual regresi kointegrasi. Pada umumnya sebagian besar pembahasan mengenai isu terkait lebih memusatkan perhatiannya pada variabel yang berintegrasi nol $\mathrm{I}(0)$ atau berintegrasi satu I(1).

\section{Pembentukan EG-ECM}

Penerapan model EG-ECM dalam analisis ekonomika tidak terlepas dari Sargan (1964), kemudian dikembangkan oleh Hendry dan dipopulerkan oleh Eangle dan Granger (1987). EG-ECM mengasumsikan adanya keseimbangan (equilibrium) dalam jangka panjang antara variabel-variabel ekonomi.

Dalam jangka pendek, bila pada suatu periode terdapat ketidakseimbangan (disequilibrium), maka pada periode berikutnya dalam rentang waktu tertentu akan terjadi proses koreksi kesalahan sehingga akan kembali pada posisi keseimbangan. Proses koreksi kesalahan ini dapat diartikan sebagai penyelaras perilaku jangka pendek yang berpotensi mengalami ketidakseimbangan ke arah perilaku jangka panjang yang mempresentasikan kondisi keseimbangan (Hardianto, 2006).

Pembentukan EG-ECM dari penelitian ini selengkapnya dapat dilakukan melalui tahap-tahap berikut:

1. Diawali dari pengembangan model persamaan awal yang menggambarkan hubungan keseimbangan dalam jangka panjang sesuai teori yang berlaku, yakni:

$G F D_{t}=\beta_{0}+\beta_{1} B D_{t}+\beta_{2} E R_{t}+\beta_{3} 119977_{t}+\beta_{4} E X R_{t}+\beta_{5} Y R_{t}+e_{t}$

Jika variabel GFD berada pada titik keseimbangan terhadap variabel independennya, maka hubungan keseimbangan antara variabel dependen dan independennya seperti persamaan (1) terpenuhi. 
UNISIA, Vol. XXXI No. 70 Desember 2008

2. Namun pada umumnya, keseimbangan tersebut sulit tercapai dan justru ketidakseimbangan yang sering muncul dalam jangka pendek. Ketidakseimbangan ini digambarkan dengan nilai Error Correction Term (ECT) yang dirumuskan sebagai berikut:

$E C T_{1}=G F D_{1}-\beta_{0}+\beta_{1} B D_{1}+\beta_{2} E R_{1}+\beta_{3} I 997,+\beta_{4} E X_{1}+\beta_{5} Y R_{t}$

$E C T_{t}$ ini disebut sebagai kesalahan ketidakseimbangan (disequilibrium error).

3. Selanjutnya untuk mengetahui secara empiris hubungan antara variabel pinjaman luar negeri pemerintah dan variabel-variabel ekonomi, peneliti tidak dapat mendeteksi nilai keseimbangan secara langsung. Namun peneliti hanya dapat melakukannya dengan mengestimasi hubungan jangka pendek dengan memasukkan unsur kelambanan sehingga model persamaannya menjadi:

$G F D_{t}=\beta_{0}+\beta_{1} B D_{t}+\beta_{2} E R_{t}+\beta_{3} I 1997_{t}+\beta_{4} E X R_{t}+\beta_{5} Y R_{t}+\beta_{1} B D_{t-1}+\beta_{2} E R_{t-1}+$

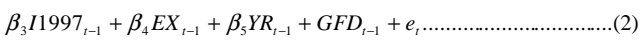

4. Persoalan utama dalam mengestimasi persamaan (2) adalah jika data ternyata tidak stasioner pada tingfkat level. Untuk mengatasinya, persamaan (2) perlu dimanipulasi dengan cara mengurangi setiap sisi kanan dan kiri persamaan (2) dengan variabel $G F D_{t-1}$. Hasilnya sebagai berikut:

$G F D_{t}-G F D_{t-1}=\beta_{0}+\beta_{1} B D_{t}+\beta_{2} E R_{t}+\beta_{3} I 1997 t_{t}+\beta_{4} E X R_{t}+\beta_{5} Y R_{t}+\beta_{6} B D_{t-1}+$ $\beta_{7} E R_{t-1}+\beta_{8} I 1997_{t-1}+\beta_{9} E X_{t-1}+\beta_{10} Y R_{t-1}+\beta_{11} G F D_{t}-G F D_{t-1}+e_{t}$ $=\beta_{0}+\beta_{1} B D_{t}+\beta_{2} E R_{t}+\beta_{3} I 1997_{t}+\beta_{4} E X R_{t}+\beta_{5} Y R_{t}+\beta_{6} B D_{t-1}+\beta_{7} E R_{t-1}+$ $\beta_{8} I 1997_{t-1}+\beta_{9} E X_{t-1}+\beta_{10} Y R_{t-1}-\left(G F D_{t-1}-\beta_{11} G F D_{t-1}\right)+e_{t}$ $=\beta_{0}+\beta_{1} B D_{t}+\beta_{2} E R_{t}+\beta_{3} I 1997,+\beta_{4} E X R_{t}+\beta_{5} Y R_{t}+\beta_{6} B D_{t-1}+\beta_{7} E R_{t-1}+$ $\beta_{8} I 1997_{t-1}+\beta_{9} E X_{t-1}+\beta_{10} Y R_{t-1}-\left(1-\beta_{11}\right) G F D_{t-1}+e_{t}$ $=\beta_{0}+\beta_{1} B D_{t}+\beta_{2} E R_{t}+\beta_{3} I 1997_{t}+\beta_{4} E X R_{t}+\beta_{5} Y R_{t}+\beta_{6} B D_{t-1}+\beta_{7} E R_{t-1}+$ $\beta_{8} I 1997{ }_{t-1}+\beta_{9} E X_{t-1}+\beta_{10} Y R_{t-1}-\lambda G F D_{t-1}+e_{t}$ Keterangan $: \lambda=\left(1-\beta_{11}\right)$

Selanjutnya, penambahan dan pengurangan

$\begin{array}{lllll}e & n & g & a & n\end{array}$
$\left(\beta_{1} B D_{t-1}+\beta_{2} E R_{t-1}+\beta_{3} I 1997_{t-1}+\beta_{4} E X R_{t-1}+\beta_{5} Y R_{t-1}\right)$ menghasilkan persamaan-persamaan berikut:

$G F D_{t}-G F D_{t-1}=\beta_{0}+\beta_{1} B D_{t}+\beta_{2} E R_{t}+\beta_{3} I 1997_{t}+\beta_{4} E X R_{1}+\beta_{5} Y R_{t}+\beta_{6} B D_{t-1}+\beta_{7} E R_{t-1}+$

$\beta_{8} I 1997_{t-1}+\beta_{9} E X_{t-1}+\beta_{10} Y R_{t-1}+\beta_{1} B D_{t-1}+\beta_{2} E R_{t-1}+\beta_{3} I 1997_{t-1}+\beta_{4} E X R_{t-1}+$

$\beta_{5} Y R_{t-1}-\beta_{1} B D_{t-1}-\beta_{2} E R_{t-1}-\beta_{3} I 19977_{t-1}-\beta_{4} E X_{t-1}-\beta_{5} Y R_{t-1}-\lambda G F D_{t-1}+e_{t}$ $=\beta_{0}+\beta_{1} B D_{1}-\beta_{1} B D_{t-1}+\beta_{2} E R_{2}-\beta_{2} E R_{-1}+\beta_{3} 11997_{t}-\beta_{3} 1997_{t-1}+\beta_{4} E X R_{7}-\beta_{4} E X R_{-1}+$

$\beta_{5} Y R_{t}-\beta_{5} Y R_{t-1}+\beta_{6} B D_{t-1}+\beta_{1} B D_{t-1}+\beta_{7} E R_{t-1}+\beta_{2} E R_{t-1}+\beta_{8} I 1997_{t}+\beta_{3} I 1997_{t-1}+$

$\beta_{9} E X R_{t-1}+\beta_{4} E X R_{t-1}+\beta_{10} Y R_{t-1}+\beta_{5} Y R_{t-1}-\lambda G F D_{t-1}+e_{t}$

$D G F D_{t}=\beta_{0}+\beta_{1} D B D_{t}+\beta_{2} D E R_{t}+\beta_{3} D I 1997_{t}+\beta_{4} D E X R_{t}+\beta_{5} D Y R_{t}+\left(\beta_{6}+\beta_{1}\right) B D_{t-1}+$

$\left(\beta_{7}+\beta_{2}\right) E R_{t-1}+\left(\beta_{8}+\beta_{3}\right) I 19977_{t-1}+\left(\beta_{9}+\beta_{4}\right) E X R_{t-1}+\left(\beta_{10}+\beta_{5}\right) Y R_{t-1}-$

$\lambda G F D_{t-1}+e$

$D G F D_{t}=\beta_{0}+\beta_{1} D B D_{t}+\beta_{2} D E R_{t}+\beta_{3} D I 1997_{t}+\beta_{4} D E X_{t}+\beta_{5} D Y R_{t}-\lambda\left(G F D_{t-1}-\right.$

$\left.\delta_{1} B D_{t-1}-\delta_{2} E R_{t}-\delta_{3} I 1997-\delta_{4} E X R_{t}-\delta_{5} Y R_{t}\right)+e_{t}$ $D G F D_{i}=\beta_{n}+\beta_{1} D B D_{i}+\beta_{2} D E R_{t}+\beta_{3} D I 1997_{1}+\beta_{4} D E X R_{i}+\beta_{3} D Y R_{,}-\lambda\left(G F D_{t-1}-\delta_{0}-\right.$

$\left.\delta_{1} B D_{t-1}-\delta_{2} E R_{t-1}-\delta_{3} I 1997_{t-1}-\delta_{4} E X R_{t-1}-\delta_{5} Y R_{t-1}\right)+e_{t}$

Keterangan :

$$
\begin{aligned}
& \partial_{0}^{G F D}=\not_{0}^{\beta_{0}+\chi^{2} D B D_{t}+\beta_{2} D} \\
& \delta_{1}=\left(\beta_{6}+\beta_{1}\right) / \lambda \\
& \delta_{2}=\left(\beta_{7}+\beta_{2}\right) / \lambda \\
& \delta_{3}=\left(\beta_{8}+\beta_{3}\right) / \lambda \\
& \delta_{4}=\left(\beta_{9}+\beta_{4}\right) / \lambda \\
& \delta_{5}=\left(\beta_{10}+\beta_{5}\right) / \lambda \\
& D X_{t}=X_{t}-X_{t-1}
\end{aligned}
$$

Setelah melalui manipulasi persamaan dan parameterisasi ulang seperti diatas, model EG-ECM yang diestimasi adalah sebagai berikut:

$D G F D_{l}=\beta_{0}+\beta_{1} D B D_{t}+\beta_{2} D E R_{t}+\beta_{3} D I 1997_{t}+\beta_{4} D E X R_{t}+\beta_{5} D Y R_{t}-\beta_{6} E C T_{t-1}+e_{t} \ldots \ldots \ldots \ldots \ldots \ldots . . . .(3)$

Dimana: $D_{\text {GFD }}=G F D_{t}-G F D_{t-1}$

(diferensi pertama pinjaman luar negeri pemerintah) 
Faktor-faktor Yang Mempengaruhi Pinjaman Luar Negeri...; Samsubar Saleh

$D B D_{t}=D B D_{t}-D B D_{t-1}$

(diferensi pertama defisit anggaran)

$D E R_{t}=D E R_{t}-D E R_{t-1}$

(diferensi pertama nilai tukar rupiah terhadap

dollar $A S)$

$D I 1997_{t}=$ DI1997 $-I 1997_{t-1}$

(diferensi pertama kriris pinjaman tahun 1997

$D E X R_{t}=D E X R_{t}-D E X R_{t-1}$ (diferensi pertama tingkat ekspor)

$D Y R_{t}=D Y R_{t}-D Y R_{t-1}$ (diferensi pertama tingkat GNP)

$E C T_{t-1}=$ Error Correction Term pada

$t-1$

$=G F D_{t-1}-\delta_{0}-\delta_{1} B D_{t-1}-\delta_{2} E R_{t-1}-\delta_{3} I 1997_{t-1}-\delta_{4} E X R_{t-1}-\delta_{5} Y R_{t-1}$

$e_{t}=$ residual

Persamaan (3) di atas menjelaskan bahwa perubahan variabel pinjaman luar negeri pemerintah (DGFD) dipengaruhi oleh perubahan variabel defisit anggaran (DBD), perubahan nilai tukar rupiah terhadap dollar AS (DER), variabel dummy krisis pinjaman tahun 1997 (I1997), perubahan tingkat ekspor (DEXR), dan perubahan tingkat pertumbuhan ekonomi atau GNP (DYR), dan Error Correction Term (ECT). Model persamaan tersebut hanya dapat diestimasi jika variabel-variabel di dalamnya terkointegrasi pada derajat integrasi yang sama. Karena itu, sebelum mengestimasi persamaan EG-ECM, terlebih dahulu dilakukan pengujian derajat integrasi dan kointegrasi.

\section{Estimasi Jangka Pendek}

Tahapan selanjutnya adalah mengestimasi hubungan jangka pendek (EGECM) dengan metode Ordinary Least Square (OLS). Setelah itu dilakukan uji signifikansi variabel penelitian, dan uji asumsi klasik terhadap hasil estimasi jangka pendek (EGECM). Dalam proses ini dapat dikeahui pengaruh variabel independen terhadap variabel dependen dalam jangka pendek termasuk validitas penelitian yang dapat dilihat dari informasi variabel ECT.

\section{Estimasi Jangka Panjang (Persamaan Kointegrasi)}

Setelah menganalisis hubungan jangka pendek, maka proses berikutnya dilanjutkan dengan menganalisis hubungan jangka panjang (persamaan kointegrasi). Dalam hal ini dapat diketahui pengaruh jangka panjang/ keseimbangan variabel makro ekonomi terhadap pinjaman luar negeri pemerintah Indonesia.

\section{Hasil dan Pembahasan}

\section{Uji Stasioneritas}

Dalam menguji perilaku data selama periode pengamatan dapat dilakukan dengan uji akar-akar unit (unit roots). Adapun metode yang digunakan adalah uji Argumented Dickey Fuller (ADF), yaitu dengan membandingkan nilai absolut statistik ADF dengan nilai absolut kritisnya distribusi statistik Mackinnon pada tertentu.

Hasil pengujian unit roots terhadap variabel-variabel yang digunakan dalam analisis ini dapat dilihat pada tabel (2) sebagaimana Tabel (2).

Hasil uji stasioneritas menunjukkan bahwa tidak semua variabel stasioner pada bentuk level karena nilai absolut statistik ADF lebih kecil daripada nilai absolut kritisnya pada tingkat signifikansi $5 \%$. Dengan demikian, maka perlu dilakukan uji integrasi untuk mengetahui pada derajat berapa variabel-variabel tersebut stasioner dalam derajat yang sama. 
UNISIA, Vol. XXXI No. 70 Desember 2008

Tabel (2) Hasil Uji Stasioneritas Bentuk Level

Keterangan:

Nilai Kritis pada $\alpha=5 \%$

\section{Uji Derajat Integrasi}

Hasil uji integrasi menunjukkan bahwa semua variabel penelitian ternyata stasioner dalam bentuk diferensi pertama. Hal itu dilihat dari nilai absolut statistik ADF yang lebih besar dari pada nilai absolut kritisnya, pada tingkat signifikansi $5 \%$. Karena itu dapat dikatakan bahwa variabel-variabel penelitian terintegrasi pada derajat yang sama, yakni derajat satu atau dengan kata lain, persyaratan untuk melakukan uji kointegrasi telah terpenuhi.

Adapun hasil uji derajat integrasi tersebut dapat dilihat pada tabel (3) sebagaimana Tabel (3).
Selanjutnya, hasil uji integrasi menunjukkan adanya hubungan kointegrasi pada model persamaan awal penelitian. Hal ini dapat diketahui dari uji stasioneritas terhadap residual yang diperoleh dari hasil estimasi model persamaan awal, yakni persamaan (1). Uji stasioneritas tersebut menunjukkan bahwa nilai absolut statistik ADF lebih besar dari pada nilai absolut kritisnya pada tingkat signifikan $5 \%$. Hasil uji stasioneritas residual (ECT) ini dapat dilihat pada tabel (4) dan (5).

Dengan demikian dapat disimpulkan bahwa model persamaan awal merupakan model persamaan kointegrasi, di mana perilaku datanya mengandung kemungkinan adanya hubungan keseimbangan jangka panjang seperti yang diharapkan oleh teori.

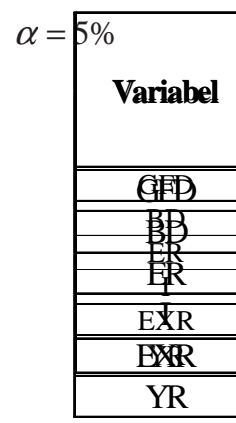

\section{Tabel (3) Hasil Uji Derajat Integrasi Pertama}

Keterangan:

Nilai Kritis pada 
Faktor-faktor Yang Mempengaruhi Pinjaman Luar Negeri...; Samsubar Saleh

Tabel (4) Hasil Uji Kointegrasi ECT pada Bentuk Level

Keterangan:

Nilai Kritis pada

Tabel (5) Uji Koinetegrasi ECT pada First Difference

Keterangan:

Nilai Kritis pada

Estimasi Jangka Pendek (EG-ECM) signifikansi variabel penelitian, dan uji

Setelah melakukan uji stasioneritas asumsi klasik terhadap hasil estimasi EG-

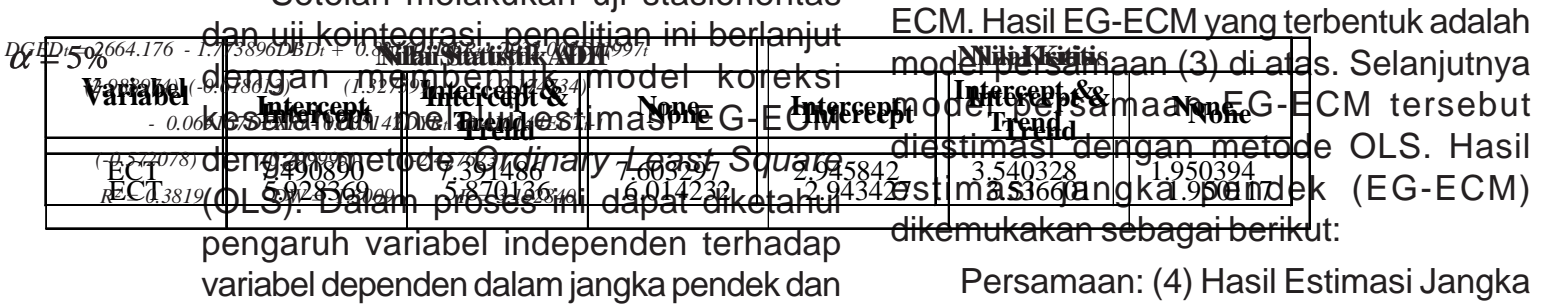
juga validitas model estimasi yang dapat diketahui dari koefisien variabel Error Correction Term (ECT). Eksistensi koreksi kesalahan menghasilkan koefisien koreksi kesalahan yang menunjukkan adanya fenomena dikoreksinya penyimpangan menuju ekuilibrium. Model koreksi kesalahan merupakan alternatif lain untuk menguji kemungkinan berkointegrasinya variabel yang diamati.

Apabila ECT dari hasil regresi signifikan berarti model koreksi kesalahan adalah model yang valid, dan variabel yang diamati berkointegrasi atau residual hasil regresi adalah stasioner. Setelah itu dilakukan uji

\section{Pendek (EG-ECM)}

Berdasarkan hasil di atas dapat dikemukakan bahwa dalam jangka pendek, variabel independen yang berpengaruh signifikan terhadap perubahan pinjaman luar negeri pemerintah Indonesia adalah variabel dummy dan variabel ECT pada tingkat signifikansi $5 \%$, dan memiliki tanda sesuai dengan yang diharapkan. 
UNISIA, Vol. XXXI No. 70 Desember 2008

Seberapa besar perubahan variabel independen tersebut berpengaruh terhadap perubahan pinjaman luar negeri pemerintah Indonesia tergantung nilai koefisien dan tanda pada hasil estimasi. Sebaliknya, dalam jangka pendek variabel defisit anggaran, nilai tukar, ekspor dan tingkat GNP tidak berpengaruh signifikan terhadap pinjaman luar negeri pemerinah Indonesia pada tingkat signifikansi 5\%.

Sedangkan untuk variabel ECT berpengaruh signifikan pada tingkat signifikansi 5\%, dan memiliki tanda negatif. Hal ini memperkuat bukti adanya hubungan kointegrasi atau hubungan jangka panjang/ keseimbangan antara variabel independen dan dependennya. Selain itu, signifikansi variabel variabel ECT juga berarti bahwa model empiris yang digunakan dalam penelitian memiliki spesifikasi model yang valid sehingga hasil estimasi EG-ECM dapat digunakan untuk melihat pengaruh variabelvariabel makro ekonomi terhadap pinjaman luar negeri pemerintah Indonesia.

Dari hasil estimasi diketahui besarnya nilai absolut koefisien variabel ECT sebesar $0.416144 y a n g$ menjelaskan bahwa sekitar $41 \%$ ketidaksesuaian antara nilai aktual pinjaman luar negeri pemerintah Indonesia dalam jangka pendek dan nilai keseimbangan pinjaman luar negeri pemerintah Indonesia dalam jangka panjang akan dikoreksi pada setiap tahunnya.
Dengan demikian, maka melalui persamaan jangka pendek di atas dapat ditaksir pengaruh jangka panjang defisit anggaran, nilai tukar, dummy, ekspor, dan tingkat GNP terhadap pinjaman luar negeri pemerinah Indonesia.

Disamping itu terbukti bahwa spesifikasi model yang dipakai adalah model yang valid seperti telah diketahui diatas, hasil estimasi ECM juga lolos dari berbagai uji diagnosis atau asumsi klasik seperti uji normalitas, linieritas, autokorelasi dan heteroskedastisitas, sekaligus membuktikan bahwa model penaksir tersebut merupakan model penaksir yang linier, tidak bias, dan terbaik/ efisien (Best Linear Unbiased Estimator, BLUE). Selengkapnya hasil uji asumsiasumsi klasik dapat dilihat pada tabel (6).

\section{Estimasi Keseimbangan Jangka Panjang}

Selanjutnya, setelah melalui beberapa tahapan pengujian seperti dikemukakan sebelumnya, maka tibalah saatnya untuk menganalisa hubungan jangka panjang variabel makro ekonomi dengan pinjaman luar negeri pemerintah Indonesia. Hubungan jangka panjang ini dapat diperoleh dengan mengestimasi model persamaan jangka panjang atau persamaan kointegrasi sebagaimana ditunjukkan pada persamaan (1) di atas.

\section{Tabel (6) Hasil Uji Asumsi Klasik Estimasi ECM}


Faktor-faktor Yang Mempengaruhi Pinjaman Luar Negeri...; Samsubar Saleh

Hasil estimasi terhadap model persamaan tersebut menunjukkan bahwa dalam jangka panjang, variabel nilai tukar (ER), ekspor (EXR), tingkat GNP (YR), dan variabel dummy (I) berpengaruh signifikan terhadap pinjaman luar negeri pemerintah, kecuali variabel defisit anggaran (FD) yang cenderung tidak berpengaruh signifikan terhadap pinjaman luar negeri pemerintah Indonesia selama periode pengamatan.

Dengan hasil ini dapat dikatakan bahwa perubahan besarnya pinjaman luar negeri pemerintah Indonesia cukup responsif terhadap perubahan yang terjadi pada variabel-variabel makro ekonomi Indonesia, khususnya variabel ekspor, nilai tukar, pertumbuhan ekonomi, dan kondisi pinjaman luar negeri pacsa krisis ekonomi tahun 1997. Hasil dari analisis tersebut telah mampu menggambarkan bahwa besarnya pinjaman luar negeri sangat dipengaruhi oleh dua variabel yang pada dasarnya sulit dikendalikan oleh pemerintah, yaitu besarnya ekspor dan tinggi rendahnya nilai tukar mata uang rupiah terhadap dolar Amerika. Bagi Indonesia, belum terlihat adanya perubahan yang cukup signifikan antara melemahnya nilai tukar rupiah terhadap kenaikan nilai ekspor yang selanjutnya dapat memperbaiki angka DSR. Begitupun dengan nilai tukar yang masih sering berfluktuasi akan menyulitkan bagi dunia usaha untuk membuat rencana bisnisnya dalam jangka panjang. Kondisi seperti ini tentunya akan mempengaruhi pula akan adanya upaya-upaya pelaku ekonomi lainnya untuk melakukan spekulasi yang berlebihan terhadap kondisi pasar valas di Indonesia.

Hasil estimasi selengkapnya dapat dilihat pada persamaan berikut:

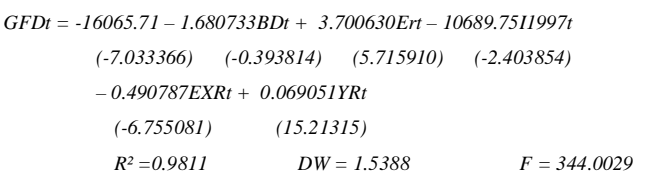

Persamaan: (5) Hasil Estimasi Jangka Panjang

\section{Imbasan Pinjaman Iuar negeri Terhadap Anggaran Pendapatan \& Belanja Negara}

Pada bagian ini akan disajikan sekelumit pembahasan tentang imbasan pinjaman luar negeri pemerintah terhadap APBN khususnya dan perekonomian Indonesia pada umumnya. Hasil analisis memperlihatkan adanya variasi atau trend yang cenderung menaik maupun menurun untuk masing-masing variabel pengamatan. Umumnya indikator tersebut dinyatakan dalam satuan persen atau rasio yang merupakan perbandingan antara dua variabel. Indikator tersebut dimaksudkan antara lain untuk mengukur "tingkat keamanan". Dengan demikian, dapat dikatakan bahwa secara keseluruhan pinjaman luar negeri pemerintah Indonesia sangat berpengaruh terhadap kondisi APBN yang ditunjukkan melalui besaran angka atau persentase DSR dari tahun ke tahun yang hingga kini masih berada diatas batas psikologis yaitu sebesar $20 \%$. Berdasarkan kondisi ini, maka APBN Indonesia masih akan mengalami tekanan karena harus memenuhi kewajiban membayar kembali jumlah pokok dan bunga pinjaman yang telah dan akan jatuh tempo di masa-masa yang akan datang.

Dari hasil tersebut terlihat bahwa ada tendensi yang kuat bahwa DSR Indonesia semakin meningkat dari tahun ke tahun dan keadaan tersebut nampaknya sudah cukup mengkhawatirkan bagi kondisi APBN di 
UNISIA, Vol. XXXI No. 70 Desember 2008

masa yang akan datang. Keadaan ini memang tidak perlu dirisaukan apabila kinerja ekspor maupun penerimanan pajak Indonesia tidak mengalami gangguan dalam jangka pendek maupun dalam jangka panjang. Namun dengan adanya krisis ekonomi yang terjadi secara global dan belum adanya tanda-tanda bahwa krisis ini akan segera berakhir, maka dampak krisis ekonomi global terhadap menurunnya ekspor sudah mulai dirasakan. Kondisi DSR Indonesia dari tahun 1970 hingga tahun 1984 menunjukkan kinerja yang sangat baik di mana rata-rata DSR dalam kurun waktu tersebut berkisar 6\%. Tahun 1985 hingga Kondisi yang semakin baik terlihat pada rasio antara besarnya pinjaman luar negeri terhadap ekspor. Hal ini memang disebabkan dalam dekade terakhir pemerintah Indonesia tidak begitu gencar untuk menambah pinjaman luar negerinya dalam membiayai defisit anggarannya. Selanjutnya dari tahun 1998 rata-rata DSR meningkat secara tajam dengan angka ratarata DSR lebih dari $50 \%$. Hasil perhitungan selengkapnya dapat dilihat pada tabel (7).

\section{Penutup}

Berdasarkan hasil-hasil pembahasan tersebut diatas, maka dapat ditarik kesimpulan sebagai berikut:

Pertama, hasil uji kointegrasi menunjukkan bahwa ada hubungan kointegrasi jangka panjang atau hubungan keseimbangan antara perubahan pinjaman luar negeri pemerintah Indonesia terhadap variabel-variabel makro ekonomi, yakni defisit anggaran, nilai tukar, ekspor, tingkat pertumbuhan GNP, dan variabel dummy krisis pinjaman 1997.
Tabel (7) Rasio Pinjaman Luar Negeri Pemerintah Indonesia (GFD) terhadap Ekspor (EXR) dan GNP serta Debt Service Ratio (DSR) 
Faktor-faktor Yang Mempengaruhi Pinjaman Luar Negeri...; Samsubar Saleh

Kedua, dari hasil estimasi EG-ECM di atas dapat dikemukakan bahwa dalam jangka pendek variabel independen yang berpengaruh signifikan terhadap perubahan pinjaman luar negeri pemerintah Indonesia adalah variabel dummy krisis ekonomi 1997 dan variabel ECT pada tingkat signifikansi $5 \%$. Sedangkan variabel defisit anggaran, nilai tukar, ekspor, dan tingkat GNP tidak berpengaruh signifikan terhadap pinjaman luar negeri pemerintah Indonesia selama periode pengamatan.

Ketiga, signifikansi variabel ECT memperkuat bukti adanya hubungan kointegrasi atau hubungan jangka panjang/ keseimbangan antara variabel independen dan dependennya. Selain itu, signifikansi variabel variabel ECT juga berarti bahwa model empiris yang digunakan dalam penelitian memiliki spesifikasi model yang valid sehingga hasil estimasi EG-ECM dapat digunakan untuk melihat pengaruh variabelvariabel makro ekonomi terhadap pinjaman luar negeri pemerintah Indonesia. Dari hasil estimasi diketahui besarnya nilai absolut koefisien variabel ECT sebesar 0.416144 yang menjelaskan bahwa sekitar $41 \%$ ketidaksesuaian antara nilai aktual pinjaman luar negeri pemerintah Indonesia dalam jangka pendek dan nilai keseimbangan pinjaman luar negeri pemerintah Indonesia dalam jangka panjang akan dikoreksi pada setiap tahunnya.

Keempat, dalam jangka panjang, pinjaman luar negeri pemerintah Indonesia dipengaruhi secara signifikan oleh nilai tukar, dummy krisis ekonomi 1997, ekspor, dan tingkat GNP, sedangkan defisit anggaran tidak berpengaruh signifikan terhadap Pinjaman luar negeri pemerintah Indonesia selama periode pengamatan.

Kelima, kondisi atau posisi pinjaman luar negeri pemerintah Indonesia saat ini berada pada angka/level yang cukup besar dan memprihatinkan sehingga menjadi beban tersendiri bagi APBN Indonesia yang setiap tahunnya harus mengalokasikan porsi yang sangat besar untuk membayar beban pokok dan bunga pinjaman yang telah jatuh tempo. Hal ini terlihat dari hasil analisis terhadap indikator pinjaman atau kerentanan eksternal, seperti debt to export ratio, debt to GNP ratio, dan Debt Service Ratio (DSR).

Berdasarkan hal tersebut di atas, setidaknya ada beberapa implikasi penting antara lain, perlunya perhatian pemerintah terhadap variabel makro ekonomi seperti nilai tukar, ekspor, tingkat GNP dan kondisi pinjaman luar negeri pemerintah pasca krisis ekonomi tahun 1997. Pemerintah perlu merencanakan dan mengambil strategi kebijakan yang kongkrit untuk mendorong laju pertumbuhan ekspor, mengupayakan kenaikan tingkat pertumbuhan GNP serta menjaga kapasitas atau kemampuan anggaran agar tetap berada pada level yang cukup aman guna menciptakan fiscal sustainability.

Selanjutnya, guna memperperbaiki kondisi pinjaman luar negeri dan perekonomian Indonesia sebagai akibat terjadinya shock atau gangguan dalam jangka pendek maka diperlukan adanya sistem peringatan dini serta pembenahan sistem kelembagaan yang lebih terpadu, transparan dan akuntabel serta dibarengi oleh adanya arus informasi yang lebih baik antara Pemerintah Indonesia, stake holder serta dunia Internasional guna menunjang tercapainya stabilitas ekonomi dalam negeri. Implikasi lainnya adalah perlu adanya komitmen dan upaya yang kuat dari pemerintah untuk mengurangi jumlah pinjaman luar negeri dan ketergantungannya terhadap pihak asing. Pemanfaatan dan peruntukan anggaran yang telah diperoleh 
UNISIA, Vol. XXXI No. 70 Desember 2008

dari pinjaman luar negeri harus dapat terealisasi dengan baik, tepat sasaran dan memenuhi kaidah akuntabilitas dengan mempertimbangkan skala prioritas pembangunan nasional serta terbebas dari berbagai masalah penyimpangan atau penyelewengan.

Akhirnya, untuk mengurangi pinjaman luar negeri maka dana-dana yang bersifat off-budget perlu dikelola oleh pemerintah secara cermat dan masuk secara resmi dalam pos penerimaan negara. "Sunset Policy" yang belum lama ini dikenalkan oleh pemerintah memang dapat dimanfaatkan untuk mendapatkan penerimaan negara dari pajak yang lebih tinggi lagi dan juga meningkatkan kesadaran masyarakat akan arti pentingnya membayar pajak secara patuh, tepat waktu dan jujur. Namun pemerintah jangan lupa pula untuk mengembalikannya hasil pajak tersebut ke masyarakat dalam bentuk penyediaan barang-barang dan pelayanan publik yang lebih baik lagi agar kesejahteraan mereka dapat meningkat secara signifikan dan berkesinambungan.

\section{Daftar Pustaka}

Badan Pusat Statistik,2005. Statistik 60 Tahun Indonesia Merdeka, Jakarta.

, Berbagai Edisi, Indikator Ekonomi, Jakarta-Indonesia.

Berbagai Edisi, Statistik Indonesia: Statistical Yearbook of Indonesia, Jakarta-Indonesia. 2007, Statistik Perdagangan Luar Negeri Indonesia : Ekspor, Jilid/ Volume I, Jakarta-Indonesia.

Badan Perencanaan Pembangunan Nasional, Tim Kajian Lintas Direktorat
Kedeputian,2004. Kajian Strategi Pendanaan Luar Negeri, Jakarta.

Cholifihani, Muhammad,2008, A cointegration Analysis of Public Debt Service and GDP in Indonesia, Journal of Management and Sosial Sciences, Vol. 4, No. 2, 68-81, http:// www.biztek.edu.pk/downloads/research/jmss, diakses tanggal 26 Januari 2009.

Cordella, Tito, Luca Antonio Ricci, and Marta Ruiz-Arranz,2005, Debt Overhang or Debt Irrelevance? Revisiting the Debt-Growth Link, IMF Working Paper, Desember, http://www.imf.org/ external/pubs/ft/wp/2005/ wp05223.pdf, diakses tanggal 27 Desember 2008.

Djamin, Zulkarnaen,1993. Pinjaman Luar Negeri serta Prosedur Administratif dalam Pembiayaan Proyek Pembangunan di Indonesia, Penerbit UI-Press.

Engle, R. F. dan C. W. J. Granger,1987. CoIntegration and Error Correction: Representation, Estimation, and Testing, Econometrica, Vol. 55, No. 2, 251-276, Marc.

Hardianto, F. N. 2006. Responsivitas Harga Saham Properti Terhadap Dinamika Ekonmi Moneter Di Indonesia: Pendekatan Error Correction Model, Jurnal Ekonomi Pembangunan, Vol. 11, No. 3, Desember.

Harinowo, C.2002, Utang Pemerintah: Perkembangan, Prospek dan Pengelolaannya, Gramedia Pustaka Utama, Jakarta. 
Faktor-faktor Yang Mempengaruhi Pinjaman Luar Negeri...; Samsubar Saleh

Hyman, D. N. 2005. Public Finance : A Contemporary Application of Theory to Policy, United States.

Insukindro, 1991., Pemilihan Model Ekonomi Empirik dengan Pendekatan Koreksi Kesalahan, Jurnal Ekonomi dan Bisnis Indonesia, Vol. 14, No. 1, 1-8.

,1992, Pembentukan model dalam penelitian ekonomi, Jurnal Ekonomi dan Bisnis Indonesia, 7: 1-17.

Javed, Z. H. dan Ahmet Sahinoz, 2005. External Debt: Some Experience From Turkish Economy, Journal of Applied Sciences, 5 (2):363-367, http:// www.scialert.net/pdfs/jas/2005/363367.pdf, Diakses tanggal 26 Januari 2009.

Karagol, Erdal,1999. External Debt and Economic Growth Relationship Using The Simultaneous Equations, University of Balikesir, Turkey.

Martin, F. M. 2008. Apositive Theory of Government Debt, Simon Fraser University, September. http://www.sfu.ca/ $\sim$ fmartin/Documents/debt.pdf, diakses tanggal 27 Desember 2008.

Prasetiantono, A. T. 1996. Utang Luar Negeri dan Defisit Transaksi Berjalan dalam Perekonomian Indonesia, Kelola, Gadjah Mada University Business Review, No. 12, V.

Ramadhan, Gaffari, dan Robert A. Simanjuntak ,2007. Dinamika Utang Pemerintah dan Kesinambungan Fiskal di Indonesia Periode 19802005: Suatu Uji Perbandingan Tiga
Pendekatan, Jurnal Ekonomi dan Pembangunan Indonesia, Vol. VIII No. 01, hal. 1-30, Juli.

Rizky Awalil dan Nasyith Majidi ,2008. Indonesia Andercover Economy: Utang Pemerintah Mencekik Rakyat, E Publishing Company, Jakarta.

Rossen, H. S. 2002. Public Finance, Omega Publishing Services, United States.

Waluyo, Joko ,2006. Dampak Pembiayaan Defisit Anggaran dengan Utang Luar Negeri terhadap Inflasi dan Pertumbuhan Ekonomi, Jurnal Ekonomi dan Pembangunan Indonesia, Vol VII, No. 1, hal 83-106, Juli.

Zainulbasri, Yuswar,2000. Utang Luar Negeri, Investasi dan Tabungan Domestik: Sebuah Survey Literatur, Jurnal Ekonomi dan Bisnis Indonesia, Vol. 15, No. 3, 280-293.

http://www.bappenas.go.id, diakses tanggal 20 Desember, 2008.

http://www.dmo.or.id, diakses tanggal 20 Desember, 2008.

http://id.wikipedia.org, diakses tanggal 6 September, 2008.

http://www.econturk.org, diakses tanggal 10 September, 2008.

http://www.bps.go.id/sector/nra/gdp/ tables.shtml, diakses, 5 April 2009.

http://www.bi.go.id/web/id/Statistik/Statistik +Ekonomi + dan+ Keuangan+ Indonesa/VersiHTML, diakses tanggal 5 April 2009. 